\title{
Československo v proměnách Evropy 20. století
}

Ve dnech 26. a 27. září 2018 se v tradičně důstojných prostorách Senátu Parlamentu České republiky odehrála mezinárodní konference s názvem „Československo v proměnách Evropy 20. století“‘. Byla výsledkem úspěšné spolupráce této instituce s Historickým ústavem Akademie věd ČR a Historickým ústavem Slovenské akadémie vied a konala se pod záštitou celé řady osobností - předsedy Senátu Parlamentu ČR Milana Štěcha, předsedy Národní rady Slovenské republiky Andreje Danka, předsedy Poslanecké sněmovny Parlamentu ČR Radka Vondráčka, předsedy vlády ČR Andreje Babiše, předsedy vlády SR Petera Pellegriniho, předsedkyně Akademie věd ČR Evy Zažímalové a předsedy Slovenské akadémie vied Pavola Šajgalíka.

Jak již naznačuje samotný název konference, byla v jejím rámci zastřešujícím zpo̊sobem pojednána většina nejdůležitějších otázek týkajících se Československa, jeho vzniku, vývoje, zániku, a to vše v mezinárodním kontextu a širších souvislostech. Velkoryse pojatý a velmi různorodý program konference značně zpřehlednilo rozdělení na jednotlivé tematické sekce.

Zahraničněpolitickou sekci zahájil svým příspěvkem k Československu v letech 1918-1948 jeden z významných hostů konference, Alain Soubigou (Université de la Sorbonne). Na něho chronologicky navázal Jindřich Dejmek (HÚ AV ČR), jenž zmapoval etapu komunistického Československa, a koreferáty, které zahrnovaly pohledy na nejbližší sousedy Československa a jejich vztahy, v nichž přispěli Miroslav Šepták (Filozofická fakulta Jihočeské univerzity), Piotr Majewski (Universytet Warszawski) a István Janek (Történettudományi Intézet). Sekci zakončil svým vystoupením na téma československé etapy dějin za druhé světové války Jan Němeček (HÚ AV ČR).

Vnitropolitická sekce byla otevřena referátem Jana Rychlíka (Filozofická fakulta UK), který aktuálním způsobem pojednal o vnitřních záležitostech Československa. Následoval obdobně laděný příspěvek Romana Holce (Historický ústav SAV), který přidal slovenský pohled. S koreferátem na téma slovanství a československá státnost se připojil Radomír Vlček (HÚ AV ČR). Poté zazněly referáty Dušana Segeše (HÚ SAV) o exilovém působení Čechů a Slováků, Jana Bureše (Metropolitní univerzita Praha) o cestě Československa k lidové demokracii a Jiř́ího Kociana (Ústav pro soudobé dějiny AV ČR) na téma československého politického systému.

V rámci ekonomické sekce představili svůj př́ispěvek týkající se hospodářské politiky Drahomír Jančík a Eduard Kubů (FF UK). Následoval komparativní referát o situaci za normalizace Christopha Boyera (Universität Salzburg). Své pohledy na ekonomické 
pozadí vzniku Československa, jeho mezinárodní ekonomické vztahy i vnitřní ekonomické souvislosti, dále přednesli Antonie Doležalová (University of Cambridge), Ivan Jakubec (FF UK), Miroslav Sabol a L'udovít Hallon a Miroslav Londák (všichni HÚ SAV).

Zajímavé referáty nabídla též sekce Stát a národ, kterou zahájil svým vystoupením Jan Kuklík (Právnická fakulta UK). Nastínil v něm komplikované národnostní otázky na pozadí klíčového mezinárodního právního vývoje. Další složité aspekty československého národnostního uspořádání představil Thomas Oellermann (Friedrich-Ebert-Stiftung Praha) rozebírající ve svém příspěvku vztahy Československa s Němci nebo koreferát Davida Hubeného (Národní archiv) na téma národnostní politiky KSČ na Podkarpatské Rusi. Ožehavé pole národnostních vztahů v Československu přiblížily také referáty Marie Schwarz (Institut für Slawistik), Attily Simona (Univerzita J. Selyeho) a Zlatice Zudové-Leškové (HÚ AV ČR).

Druhý konferenční den zahrnující další dvě sekce (sociální a kulturní) přinesl další, neméně pozoruhodná témata. Sociální sekce započala referátem Jakuba Rákosníka (FF UK) rozebírajícím sociální rozměry Československa. O souvisejících otázkách navázal Milan Hlavačka (HÚ AV ČR), zabývající se úlohou expertů ve státě, a rovněž i koreferáty Oleksandra Kravčuka (Vinnická státní univerzita), Matěje Bílého a Jakuba Šloufa (Ústav pro studium totalitních režimů), Stanislava Holubce a Jana Slavíčka (oba HÚ AV ČR).

Kulturní sekci zahájil svým vystoupením týkajícím se turbulentních proměn československé kulturní scény Jiří Knapík (Slezská univerzita). Další příspěvky v této sekci rozvinuly širší souvislosti kulturního vývoje Československa od papežské politiky z úst Ruperta Kliebera (Universität Wien), přes utváření veřejného obrazu E. Beneše od Pavla Dvořáka (Masarykova univerzita), kulturu na Slovensku Eleny Londákové (HÚ SAV), až po normalizační kulturní zásahy zmíněné v příspěvku Jaroslava Šebka (HÚ AV ČR).

Oba konferenční dny byly bohatě vyplněny mnoha podnětnými a inspirativními (někdy i bouřlivějšími) diskuzemi vedenými nejen v rámci programu, ale též během přestávek. Konference „Československo v proměnách Evropy 20. století “ představila, nastínila a snad také poněkud osvětlila a objasnila řadu otázek souvisejících s Československem a jeho vývojem v proměnách času. Jak je ovšem v takovýchto př́padech obvyklé, vyvolala rovněž řadu otázek nových. Ty se, doufejme, stanou motorem další vědecké práce a přinesou nové poznatky do následujícího poznávání československé historie.

doi: 10.14712/2464689X.2018.61

Daniela Němečková, Tereza Blažková 